1998年 5 論文受付

1998年 8 䜒齐埋

Code No.25 1

\section{心抬動によるモーションアーチファクト軽減のための 高時間分解能再構成アルゴリズム}

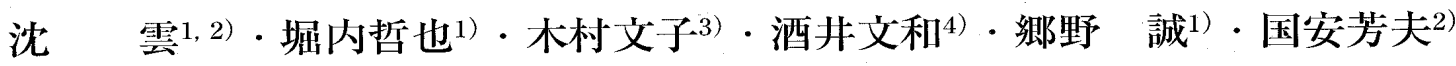

\section{1. 序 論}

心大血管病变㧍よび高分解能 CT (high resolution $\mathrm{CT}$ ：以下， HRCT）による肺病変のCT診断において, 呼吸，心拍動，体動などによる、モーションアーチファ クトを軽減することは非常に重要であり，われわれは CTのハードウエアとソフトウエアの而面から, 時間
分解能改善とモーションアーチファクトの軽減に取り 組んできた。スキャン時間を短縮することが，時間分 解能改善とモーションアーチファクトの軽減に最も有 効であり，近年実用化された0.8秒前後のsubsecond CTは，心大血管，肺領域での応用が期待されている が，これを用いても心拍動による画質低下は依然残存

\title{
High Temporal Resolution Reconstruction Algorithm to Reduce Cardiac Motion Artifact
}

\author{
YUN SHEN ${ }^{1), 2)}$ ( TETSUYA HORIUCHI') • FUMIKO KIMURA ${ }^{3)}$ - FUMIKAZU SAKAI ${ }^{4)}$ \\ MAKOTO GONO ${ }^{1)}$ and YOSHIO KUNIYASU ${ }^{2)}$
}

1) CT Laboratory, Research and Development Department, GE Yokogawa Medical Systems, Ltd.

2) Radiology Department, Showa University Fujigaoka Hospital

3) Radiology Department, Tsuchiya General Hospital

4) Radiology Department, Tokyo Women's Medical College

Received May 20, 1998; Revision accepted Aug. 24, 1998; Code No. 251

\section{Summary}

Cardiac pulsation is the most important cause of serious image degradation on high resolution CT(HRCT) images of lung adjacent to heart and cardiac images. The purpose of this study was to propose a special high temporal resolution reconstruction (HTRR) algorithm, and to assess the effects on the reduction in motion artifacts caused by cardiac pulsation on HRCT images of lung and cardiac images by using this algorithm combined with sub-second CT. The HTRR algorithm was developed on the basis of a special weighting function. The results of phantom and clinical studies demonstrated that the HTRR algorithm can provide high temporal resolution, substantially reduce motion artifacts and noise, and markedly improve the quality of cardiac images and HRCT lung images at the cost of a slight degradation in spatial resolution. Further, the HTRR algorithm can obtain phase information by combining subsecond CT with the overlapping cine reconstruction technique and ECG information. Using the HTRR algorithm, the effective temporal resolution (FWHM) is $0.4 \mathrm{sec}$ for a $0.8 \mathrm{sec}$ scan.

Key words: X-ray CT, Motion artifact, Temporal resolution, High resolution $C T(H R C T)$ lung image, Cardiac image. 
している1-5'。そこで，わ机われは心拍動によるモー ションアーチファクト軽減を目的として，高時間分解 能再構成 (high temporal resolution reconstruction : 以 下，HTRR）アルゴリズムを開発した。 HTRRアルゴリ ズムを用いることにより，実效時間分解能の向上，信 号雑音比の向上抢よびモーションアーチファクトの軽 減が得られ，さらに，subsecond CTおよび心電図によ る時相情報を併用することにより，心拍動のモーショ ンアーチファクトを軽減する強力なCT applicationと なることが期待される。本論文では，HTRRのアルゴ リズムを説明㐫るとともに，従来のアルゴリズムと比 較しながら，種々のファントムを用い，HTRRの有用 性を検討した。また，HTRRの臨床的有用性6.7につい ても若干検討した。

\section{HTRRアルゴリズム}

今回われわれが開発した高時間分解能再構成 (HTRR) アルゴリズムは, 従来の再構成アルゴリズム に特殊なweight functionを加えたものである。この weight functionである $\omega(\beta, \gamma)$ は次の式(1)で表すこと ができる。

$$
\omega\left(\beta_{1}, \gamma\right)=b /(a+b)
$$

また，

$$
\omega\left(\beta_{2}, \gamma\right)=1-\omega\left(\beta_{1}, \gamma\right)=a /(a+b)
$$

ここで， $a$ と $b$ はそれぞれ対向関係にある 2 点のデー 夕を採集するときの時間である。したがって，HTRR アルゴリズムとは，一回転データの中心である180度 ( $\pi)$ のきの時間を再構成の中心時間としたとき，こ の再構成中心時間から離れた時間 $(a, b)$ で得られた 点のデータを用いた線形補間方法である。式(1)を角

\section{ITRR Algorithm and Temporal Profile:}

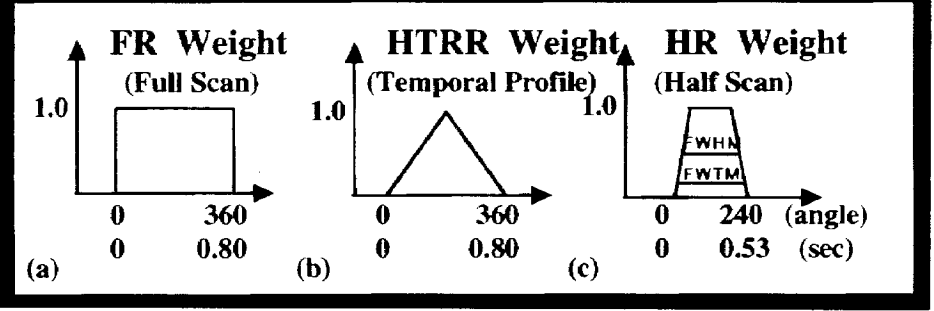

Fig. 1 HTRR algorithm.

(b) shows a triangular-shaped weighting function of the HTRR algorithm, which simultaneously delineates a temporal resolution profile of the HTRR algorithm.

(a) and (c) show, respectively, temporal resolution profiles of the current full reconstruction algorithm and half reconstruction algorithm.
度 $\beta$ 用いて示すと，以下の式(2)になる。

$$
\omega\left(\beta_{1}, \gamma\right)=\left(\beta_{2}-\pi\right) /\left(\beta_{2}-\beta_{1}\right)
$$

また，

$$
\omega\left(\beta_{2}, \gamma\right)=\left(\beta_{1}-\pi\right) /\left(\beta_{1}-\beta_{2}\right)
$$

したがって，HTRRアルゴリズムによって得られたデ 一タセットは次の式(3)で表すことができる.

$$
D_{\mathrm{h}}(\beta, \gamma)=\omega(\beta, \gamma) \times D(\beta, \gamma)
$$

ここで, $\omega(\beta, \gamma)$ はHTRRアルゴリズムのweight functionであり，式(1)あるいは(2)で表すことができる。

$$
\begin{aligned}
D(\beta, \gamma) & : \text { originalデータセット. } \\
D_{\mathrm{h}}(\beta, \gamma): & \text { HTRRアルゴリズムによって得られた } \\
& \text { データセット. }
\end{aligned}
$$

式(1)〜 (3), ならびにFig.1bの模式図で示さ机てい るように，HTRRアルゴリズムとは，画像再構成に使 用される一回転デー夕の中心である180度を再構成の 中心とし，この中心部の重み係数を最大の1.0とし， 中心からず狆た部位では，スキャンデータのずれに比 例した三角形状の線形重み付けを行う再構成方法であ る.すなわち, 式(1)で示されるごとく, HTRRアル ゴリズムとは，一回転データの中心である180度のと きの時間を再構成の中心時間とし，離れた時間 $(a, b)$ で得られた 2 点のデー夕および時間の逆比例を用いた 線形補間方法である。また，HTRRアルゴリズムと は，時間分解能が不良なデー夕セットから式(3)を用 いて再構成の中心時間に得られた高い時間分解能を有 するデータセットと同等なデータセットを作製する方 法とも言い換えることができる。このため，HTRRア ルゴリズムを用いることにより，時間分解能 の向上，モーションアーチファクトの軽減が 可能となると考えられる。な⿰子小，Fig.1bの模 式図は同時にHTRRアルゴリズムの時間分解 能のプロフィールをも示している，比較のた め, 従来の再構成アルゴリズムである full reconstruction(以下，fullリコン)アルゴリズム とhalfリコンアルゴリズムの時間分解能プロ フィールをそれぞれFig.1a，c に示す8． HTRRアルゴリズムのweight functionである $\omega(\beta, \gamma)$ のすへての值を1.0で固定すると, 式 (3)で示されたHTRRアルゴリズムは従来の fullリコンアルゴリズムになる.

本研究において時間分解能プロフィールの 
概念は非常に重要であるが，スライスプロフィールの 概念に比べ，馴染みが薄い，Fig.10ごとく，時間分 解能プロフィールの評価には, ヘリカルスキャンの際 のスライスプロフィール，与なわち，軸方向の空間分 解能プロフィールの評価と同じように，半值偪である FWHM (full width at half maximum) と 1/10 幅である FWTM (full width at tenth maximum)を用いることが できる. 本研究で取り上げている三つの再構成アルゴ リズムの時間分解能プロフィールの評価をTable 1 にま とめた．表に示されるごとく，従来の0.8秒のfullリコ ンアルゴリズムと比較し，HTRRアルゴリズムでは実 効時間分解能を半減することができ，FWHMは0.4秒 となることが分かる。

\section{3. 検討対象}

\section{3-1 ファントム}

検討対象としたファントムは，自家製の拍動する心 臓ファントム (pulsating cardiac phantom), CATPHAN phantom (空間分解能ファントム, 密度分解能ファント ムとノイズファントム) (The Phantom Laboratory社製： USA)である. pulsating cardiac phantomは本研究のた めにわれわれが独自に開発したもので, Fig.2で示され ているように, 基本的に駆動部分, 支柱部分, ファン トム部分によって構成されている(なお，その心臓ファ ントムの開発を含む評価等の詳細は別の機会に譲る). 駆動部分はサーボモータによって構成され，速度およ び周期を自由に設定することができる，支柱部分はア 一チファクトを生じにくい材質によって構成され，フ アントムの形状を決めることができる.ファントム部 分はゴムで作成され，内部に空気，水あるいは造影剂 を簡単に注入できる構造になっている。このファント ムは，心拍動のごとく，X，Y方向に連続して連動する ことができ(Z方向は固定されている), さらに運動周期 (心拍数)を自由に設定することができる.今回は，フ アントムの静止状態抢よび40, 60cycles/min.の拍動状 態にして，スキャンを行った．HTRRアルゴリズムの 基本性能を評価するためには，CATPHAN phantomを 使用した。CATPHAN phantomは空間分解能ファント ム, 密度分解能ファントム, ノイズファントム, MTF ファントムとスライス厚の評価ファントムによって構 成され，へリカルスキャンの評価にも使用されてい る.今回は, これらのうち, 空間分解能ファントム (high contrast), 密度分解能ファントム（low contrast)，ノイズファントムを用いた。

\section{3-2 臨床例}

HTRRアルゴリズムの臨床的有用性を確認するため に，肺の HRCTが施行された 5 症例を対象とした。
Table 1 Temporal resolution of the three algorithms.

\begin{tabular}{c|c|c}
\hline \hline Recon. type & FWHM & FWTM \\
\hline FR (full) & 0.80 & 0.80 \\
HTRR & 0.40 & 0.72 \\
HR (half) & 0.40 & 0.50 \\
\hline
\end{tabular}

\section{4. 方 法}

使用したCT装置はGEYMS社製CT装置Proseed SA で，スキャン時間 0.8 秒，スライス厚 $1 \mathrm{~mm}$ ズあ. スキャンモードとしては, Fig.3のごとく, cluster scan mode 抢よびcine scan modeの 2 種類を使用した. cluster scan modeは従来のスキャン方法であり，これ により得られたデータに対して，従来のfullリコンア ルゴリズム， halfリコンアルゴリズムおよび今回開発 されたHTRRアルゴリズムを用いて再構成を行った. cine scan modeとは，テーブルを移動せずに同一部位 で連続スキャンを行う方法であり，これにより得られ たデータに対しては, fullリコンアルゴリズムと HTRRアルゴリズムを使用して再構成を行うた。

動きのあるpulsating cardiac phantomに対してはcine scan mode, CATPHAN phantomに対してはcluster scan modeを用い, 臨床例では 5 例中 2 例でcine scan mode, 3 例でcluster scan modeを用いてスキャンした。な お，ファントム，臨床例ともにcine scan modeを用い た場合には，overlapping reconstruction(再構成ピッチ 0.1 ，再構成間隔 0.08 秒）を施行した。

\section{5. 結 果}

\section{5-1 ファントム}

Fig.4に, pulsating cardiac phantomの結果を示す. Fig.4aにはファントム静止状態の横断像，Fig.4b一eに

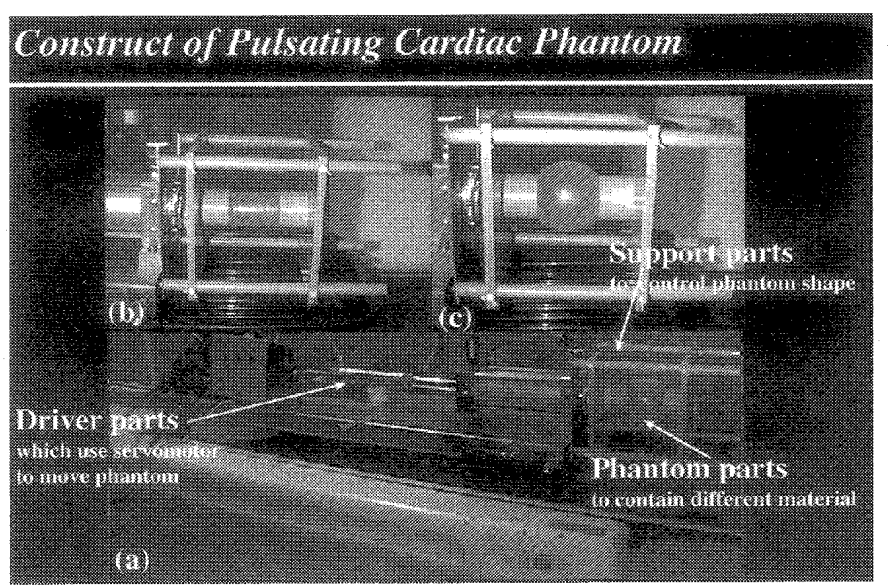

Fig. 2 Pulsating cardiac phantom.

(a) shows a view of the pulsating cardiac phantom. (b) and (c) show, respectively, the ES (end-systolic) and ED (end-diastolic) phases in the resting state of the phantom. 


\section{Scan Mode with HTRR:}

(I) Cluster Scan Mode ( $1 \mathrm{~mm}$ TH, $5 \mathrm{~mm}$ Interval in HRCT):

(a)

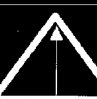

Recon Center 'Time and Position lime and Position Time and Position

(II) Cine Scan Mode (0.1RP for 4 Rotation: 0.08sec)
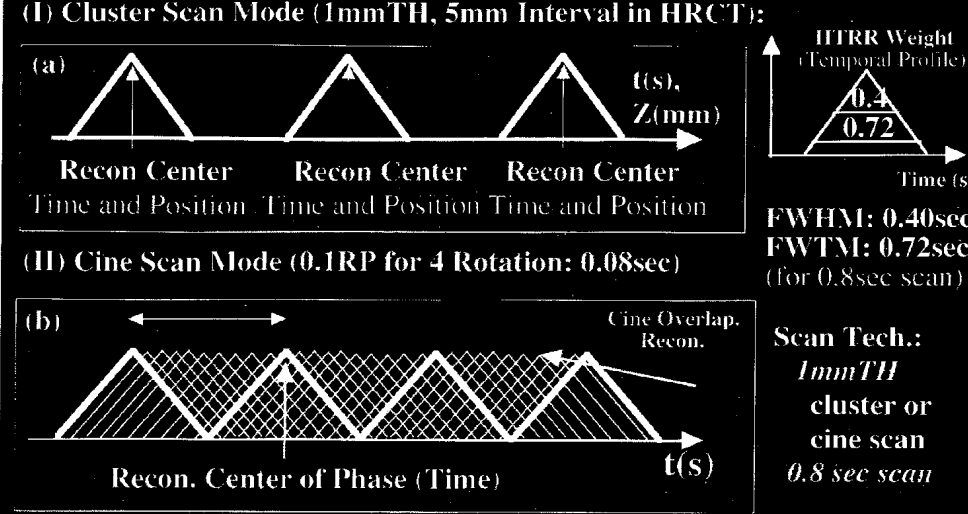

Time is

FWHII: $0.40 \mathrm{sec}$ FWTM: $0.72 \mathrm{sec}$ (lor $0.8 \sec ^{2} \mathrm{sca}$ )

Sian Tech.: ImnTH

cluster or

cine scan

0.8 sec scan

Fig. 3 Scan modes

(a) Cluster scan mode.

(b) Cine scan mode. Images of the cine scan mode are obtained using an overlapping reconstruction technique.

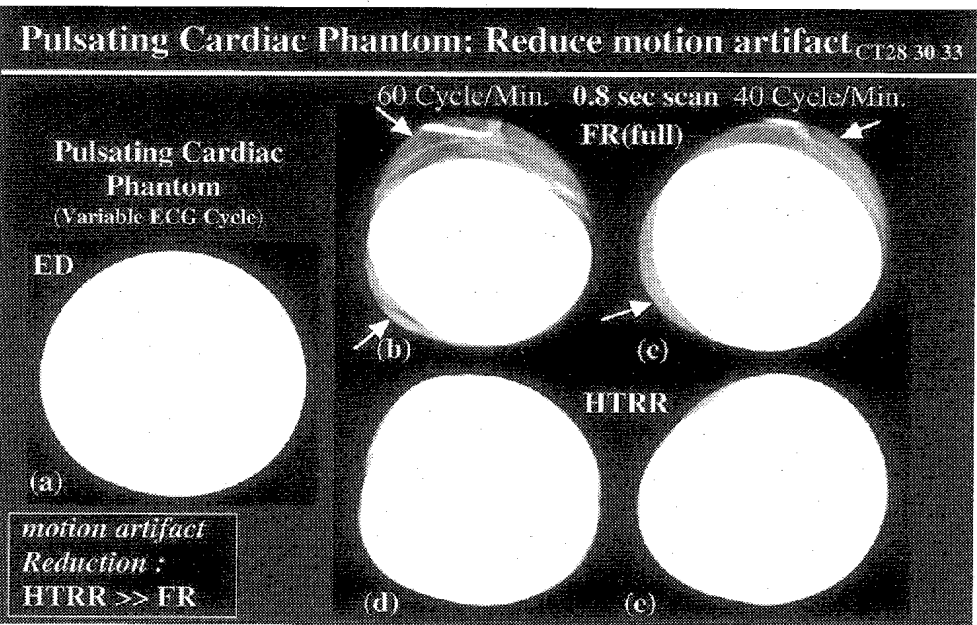

Fig. 4 Results in a pulsating cardiac phantom.

(a) shows an image of the phantom in standstill state. The four right-hand images (b-e) show results using different algorithms in dynamic states: (b)current full reconstruction algorithm with 60 cycles/min., (c) full reconstruction algorithm with 40 cycles/min., (d) HTRR algorithm with 60 cycles/min., (e) HTRR algorithm with 40 cycles/min.. Motion artifacts are significantly suppressed with the HTRR algorithm. は60㧍よび40cycles/min.にて拍動させながらcine scan を施行し，fullリコンアルゴリズムとHTRRアルゴリ ズムにより再構成した横断像を示す (fullリコンは Fig.4b, c, HTRRはFig.4d, e).いずれの画像も， overlapping reconstruction後 (再構成ピッチ 0.1 ), 多数 の再構成画像内よりファントムが最大に拡張した時相 を選択した. fullリコンアルゴリズムでは，周期の短 い(動きの激しい) 60cycles（Fig.4b）の方が，周期の長 い(動きの遅い)40cycles (Fig.4c)より，モーションア 一チファクトが著明である。一方，HTRRアルゴリズ ムを用いると，60，40cyclesの条件下に得られた結果 (Fig.4d，e)はほほ同じであり，両者ともモーションア 一チファクトはほとんど認められず，ファントムの横 断像の辺縁は鮮明に描出された。これらの結果より,
HTRRアルゴリズムは時間分解能の改善のみで なく，モーションアーチファクト軽減にも有 効であることが証明された。

HTRRアルゴリズムの基本性能評価のために 施行したCATPHAN phantomの結果をFig.5お よびFig.6に示す.いずれのファントムも cluster scan modeにて撮像後, full リコンアルゴリズ ム, halfリコンアルゴリズムおよびHTRRアル ゴリズムを用いて画像を再構成した。空間分 解能はfullリコンアルゴリズム (Fig.5a), halfリ コンアルゴリズム(Fig.5c)，HTRRアルゴリズ ム (Fig.5b)の順に優れていた。密度分解能抢よ びノイズでは, halfリコンアルゴリズム (Fig.6c，f)が一番不良で，HTRRアルゴリズム (Fig.6b, e) とfullリコンアルゴリズム (Fig.6a, d）は同程度であった。これらの結果より， HTRRリコンアルゴリズムは，従来のリコンア ルゴリズムに比べ，空間分解能の点では劣る が，密度分解能，ノイズの点では同等もしく は優れていることが証明された。

\section{5-2 臨床例 6,7$)$}

臨床例を用いた結果をFig.7，8に示す。 cluster scanを施行した 3 例すべてで， fullリコ ンアルゴリズムおよびhalfリコンアルゴリズムに 比ベて, HTRRアルゴリズムでは心拍動のモー ションアーチファクト軽減により画質の改善が 得られた(Fig.7)。HTRRアルゴリズム (Fig.7b) はhalfリコシアルゴリズム $(\mathrm{Fig.7c})$ に比べて，時 間分解能の点(FWTM, Table 1) では劣っている が，モーションアーチファクトを軽減すること ができ，高画質のHRCTの画像を得ることがで きた。

cine scanを施行した2例のいずれでも， fullリ コンアルゴリズム $($ Fig.8 $\sim \mathrm{a}$ ) に比べてHTRRアルゴリ ズム $($ Fig.8d〜f)では心拍動によるモーションアーチフ アクトを軽減することができ，HTRRアルゴリズムを 用いると肺血管陰影も 1 本の線として描出することが 可能であった。 また, overlapping reconstructionにより 得られた異なる時相の画像を検討すると, 時相により モーションアーチファクトの程度は異なり，心拍動に よるモーションアーチファクト軽減程度の差は, 画像 再構成時のweight function中心の時間における心拍動の 影響(心室の拡張期或は収縮期)の程度によることが判 明した(Fig.8).

Fig.9には，息止めを施行していない症例に対して施 行したcluster scanの画像を示しているが, fullリコン アルゴリズム $(\mathrm{a}, \mathrm{b})$ と比較すると, HTRRアルゴリズ 
ム $(\mathrm{c}, \mathrm{d})$ では呼吸によるモーションアーチフ アクト (streak artifact) も軽減可能であった.

\section{6. 考 察}

モーションアーチファクトによるCT画質の 劣化は永遠の課題である。なぜならば，CT画 像の再構成 (リコン)は，数学的に矛盾のない 投影データセットが常に得られるというこ と，すなわち投影データセット収集時には被 検体は静止しているという仮定のもとに成り 立っているからである。しかし，実際には患 者の体動，呼吸，心拍動などの動きがあり， これらの影響が画像上にモーションアーチフ アクトとして観察される。患者の比較的遅い 体動は従来のモーション補間アルゴリズムを 用いて補正可能であり, 呼吸の影響は通常の 息止めによって解決されている。たたし，心 拍動を停止してスキャンすることは不可能で あり，また，心臓は縦隔内で，X，Y，Z方向 に連続して複雑かつ非常に速く運動してい る。このため，心臓のCT診断といえば，その 優れた時間分解能のため，電子ビームCTによ るものが主流であり，現在最も普及している 第三世代CTが心臓のCT診断に利用されること は少ない(1 5)，以前には，心電闵同期再構成術 を利用した第三世代CTを用いて心疾患診断が 試みられたこともあった。この再構成術は， 同一平面の数回のスキャンを行い，心電図情 報を元にして同位相rawデータを収集，再構成 するものであり，良好な時間分解能を得るに は有效な手段であるが，煩雑性のために現在 ではほとんど利用されていない。

肺腫瘍やびまん性肺疾患の診断に打ける高 分解能CT (HRCT)の有用性はすでに確立され たものであり，部分体積現象のない薄層CTと 高い空間分解能により肺病変の微細な形態が 描出可能である。しかし，HRCTにおいても， 患者の体動，呼吸，心拍動による画質劣化は 重大な問題点である。心拍動によるモーションアーチ ファクトは心臓近傍の肺野にみられ，特に心左縁に接 する左下葉内側よりの肺野と心右辺縁下部に接する中 葉S5内側の肺野で日立つことが多い.このモーション アーチファクトにより，本来は 1 本の線である心゙き葉 間胸膜が 2 本に見えたり，血管陰影の辺縁が不鮮明に なったり， streak artifactがみられることがあり，また これらの部位に存在する異常陰影はその辺縁の性状が 不明瞭になりやすい。また，子供や年寄など息止めが 困難な患者では，呼吸によるモーションアーチファク

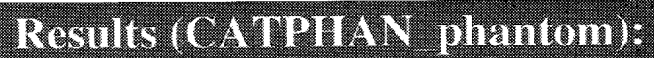
112811:

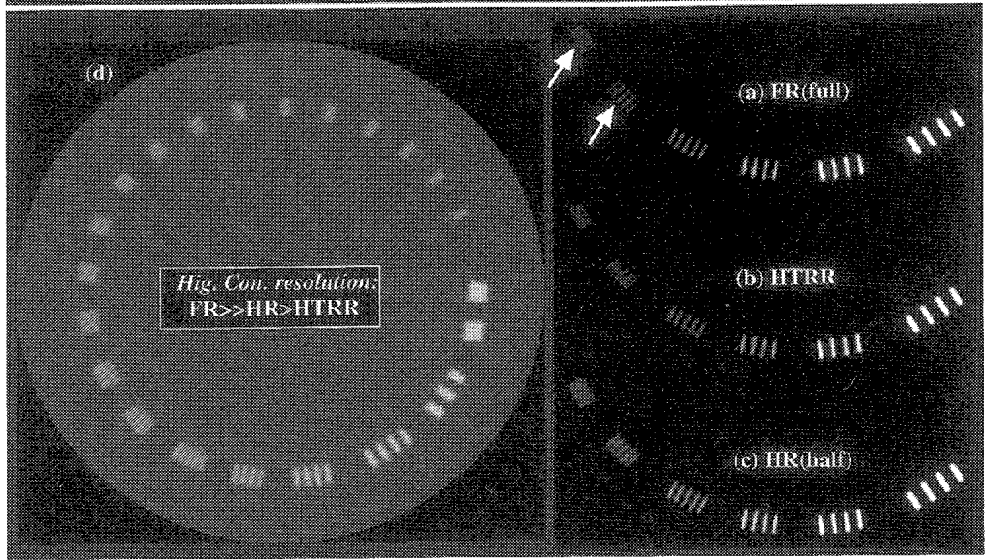

Fig. 5 Results in the CATPHAN phantom (high contrast resolution phantom).

Results of spatial resolution using three different algorithms: (a) full reconstruction algorithm, (b) HTRR algorithm, and (c) half reconstruction algorithm. (d) shows the sharpness of the high contrast resolution phantom (CATPHAN phantom). The full reconstruction algorithm provided the highest contrast resolution among the three algorithms.

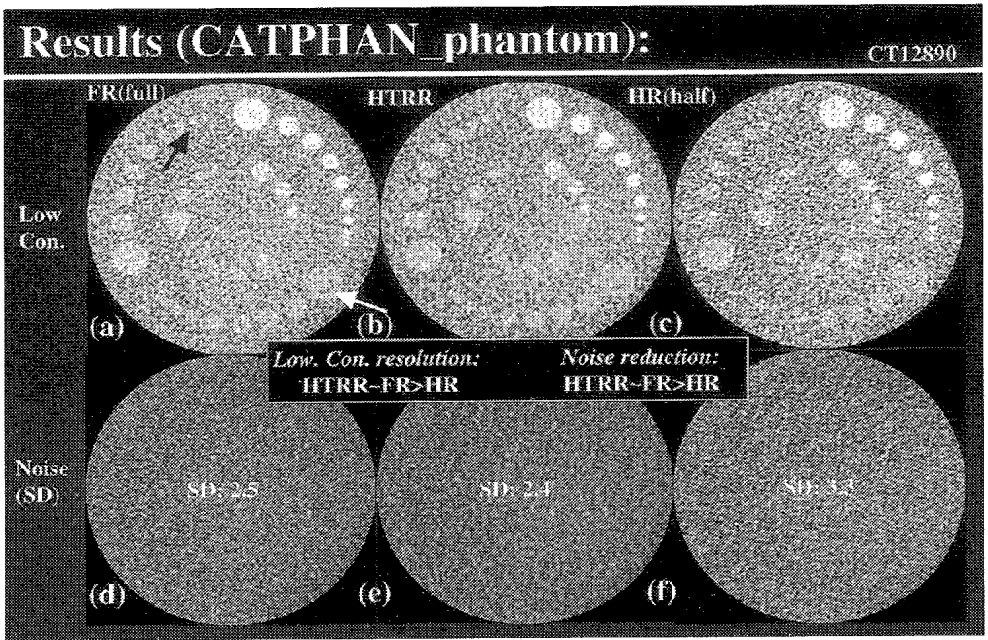

Fig. 6 Results in the CATPHAN phantom (low contrast resolution and noise phantoms).

The top row $(a-c)$ and bottom row $(d-f)$ show results from a low contrast resolution phantom and noise phantom, respectively. (a) and (d): full reconstruction algorithm, (b) and (e): HTRR algorithm, $(c)$ and $(f)$ : half reconstruction algorithm. The HTRR algorithm provided better low contrast resolution and less noise than the half reconstruction algorithm.

トも問題となり，さらに，最近では，呼吸をさせなが らスキャンし，動的診断をしようとする試みも始まっ ている。

今回の検討より，心拍動による肺HRCTの画質低下 を改善するためには，時間分解能の改善とモーション アーチファクトの軽減の両者が重要であることが判明 した．時間分解能の改善とモーションアーチファクト の軽減に関して，われわれの開発したHTRRアルゴリ ズムと従来のリコンアルゴリズムであるfullおよびhalf リコンアルゴリズムの比較をTable 2 によめた。 full 
リコンアルゴリズムは時間分解能の改善とモーション アーチファクトの軽減の両者に劣っており，心拍動の

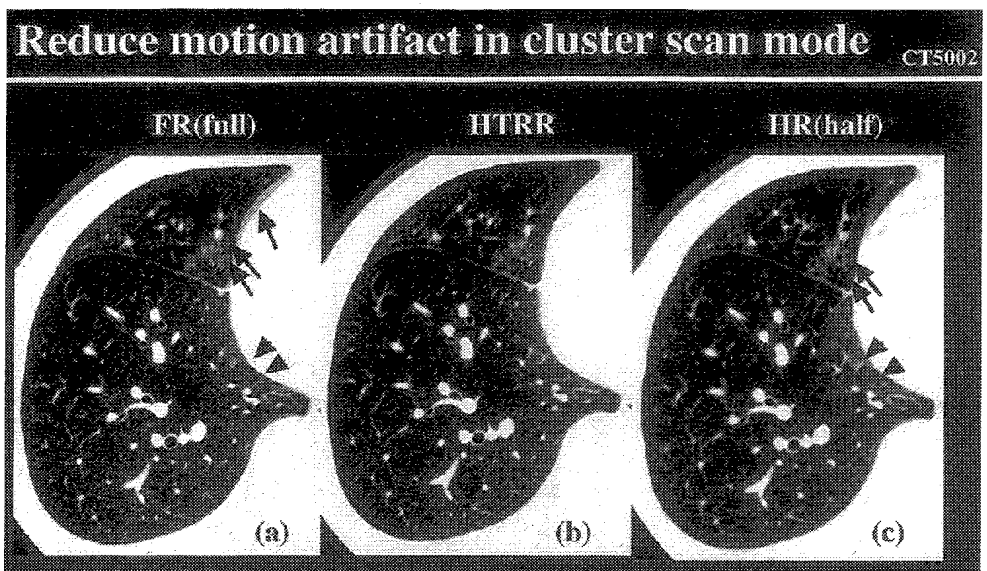

Fig. 7 Typical images of lung HRCT obtained with cluster scan mode.

(a) An image obtained with a full reconstruction algorithm. Due to motion artifacts, the cardiac silhouette is delineated as double lines, margins of pulmonary vessels are obscure in the right middle lobe, and hazy shadows are demonstrated in the right lower lobe.

(b) An image obtained with an HTRR algorithm. Margins of the cardiac silhouette and pulmonary vessels are sharp due to marked reduction of motion artifacts.

(c) An image obtained with a half reconstruction algorithm. Despite the sharp cardiac silhouette due to good temporal resolution, margins of pulmonary vessels are obscure and motion artifacts remain in the right middle and lower lobes.

\section{Reduce motion artilact in cine scan made cruses}

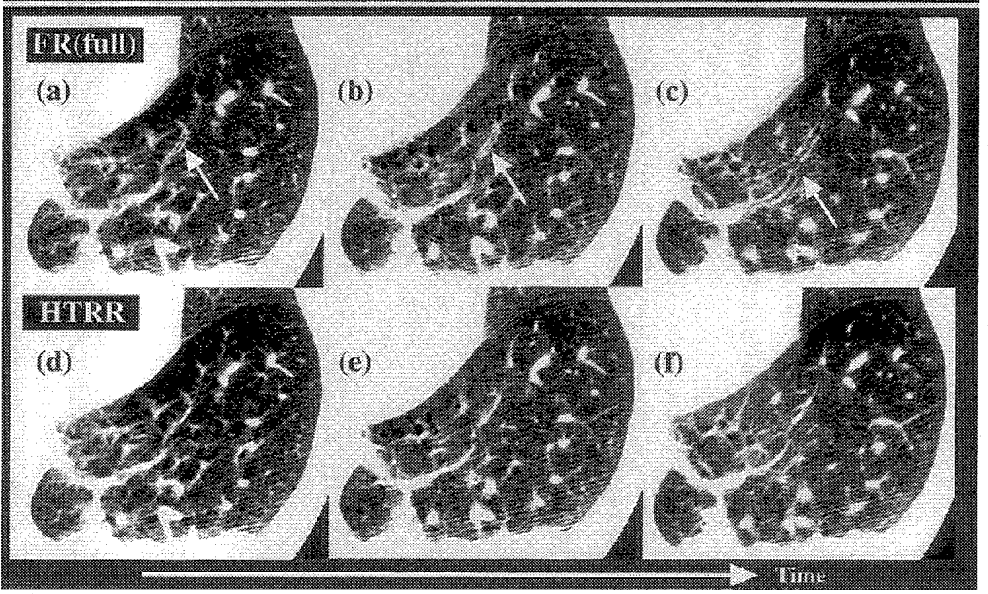

Fig. 8 Typical images of lung HRCT obtained with cine scan mode. (a) - (c): images obtained with a full reconstruction algorithm. (d) - (f): images obtained with a full reconstruction algorithm. Since different phase images are selected after overlapping reconstruction, (a), (b), (c) and $(d),(e),(f)$ show the same position and different phase images [images of (a) and (d), (b) and (e), and (c) and (f) have the same phase]. Using a full reconstruction algorithm, a pulmonary vessel in the left lower lobe is delineated as double lines due to motion artifacts. The degree of motion artifact differs with the different phases. With an HTRR algorithm, motion artifacts are significantly reduced regardless of phase. 影響を一番受けやすい再構成法である．halfリコンア ルゴリズムは最良の時間分解能を有するが，モーショ ンアーチファクトの軽減の点では劣っている。

一方，HTRRアルゴリズムは，良好な時間分解 能を有し，モーションアーチファクトを軽減す ることも可能であり，心拍動の影響を一番受け にくい再構成法ということができる.

HTRRアルゴリズムでは，従来のfullおよび halfリコンアルゴリズムに比べて，軽度の空間 分解能の低下が認められた (Fig.5)。この空間 分解能の低下は, HTRRアルゴリズム特有のも のであり，特殊なweight functionを有する三角 形状(Fig.1)の線形重み付けを行うことによっ て必然に生じるものと考えられる。一方, HTRRアルゴリズムでは，この三角形状の線形 重み付けを用いることにより, 従来のリコン アルゴリズム, 特にhalfリコンアルゴリズムに 比べて，著しくノイズを低減することが可能 であり，このため優れた密度分解能を得るこ とができたと考えられた(Fig.6)。式(3)をその まま使うと, HTRRアルゴリズムでは, 理論的 に従来のfullリコンより画像ノイズは多くなる と考えられるが, 本研究において, quarterquarter offset方式の特徽を利用し，情報量を倍 にした後に再構成を行っているので, 理論的 に従来のfullリコンよりも画像ノイズが少なく なると考えている。

臨床例の検討より，3 種類のアルゴリズムを 比較して，HTRRアルゴリズムを用いることに より最良の画質が得られたが(Fig.7)，これ は, HTRRアルゴリズムによる時間分解能の改 善と心拍動によるモーションアーチファクト 軽減効果が，空間分解能低下による影響を上 回っているためと思われた。これらの点よ り，良好な時間分解能を有し，モーションア 一チファクトを軽減することができ，さらに 良好な信号対雑音比を有しているHTRRアルゴ リズムは，心蔵領域および肺のHRCTに適する アルゴリズムと考えられる。また，息止めが 困難である患者に拈いても，時間分解能とモ ーションアーチファクトに優れているHTRRア ルゴリズムは有用であり(Fig.9)，最近施行さ れるようになった呼吸をさせながらスキャン するという動的診断のニーズにも対応できる ことが期待される。

一方，HTRRアルゴリズムは，良好な時間分 解能を有するとともに，へリカル補間アルゴリ ズム2,3) と同様に，再構成の時間中心(位相中心) 
を有しているので, cine scan撮像後overlapping reconstructionにより時相の異なる多数の画像を 得ることができる(Fig.8). 肺CT画像に対する 心拍動の影響は拡張早期のいわゆる等容性弛緩 期に最も少ないと報告されていることより6,7), HTRRアルゴリズムと心電図情報を組み合わ せ，等容性弛緩期の画像を抽出することがで きれば，さらに良好な画像が得られるものと 期待される。 なお, cine scanでは被曝線量の増 加が問題であるが，HTRRアルゴズムはノイズ 軽減が可能であるため, 被曝線量の増加を最 小限に抑えることが可能と考えている.

近い将来，スキャン時間のさらなる短縮が 可能となり，0.4〜0.6秒のfull scanを有する第 三世代高速CTが出現した際には，高速CTと HTRRアルゴリズムの組み合わせにより，電子 ビームCTと匹敵できる画像が得られる可能性 があると思われる。

\section{7. 結 論}

われわれの開発したHTRRアルゴリズムは，従来のリ コンアルゴリズムに比べて, 実效時間分解能の向上, モ ーションアーチファクトの軽減, 信号対雑音比の向上 を図ることが可能であった. subsecond CTにHTRRア ルゴリズムを組み合わせることにより，心拍動执よ゙ 呼吸によるモーションアーチファクトは著明に改善さ れ，肺のHRCT画像に適した再構成法と考えられた。

なお，本論文の要旨ならびに内容の一部は第53回日 本放射線技術学会総会学術大会ならびに国際学会であ る'97 RSNA (Radiological Society of North America) において発表した。

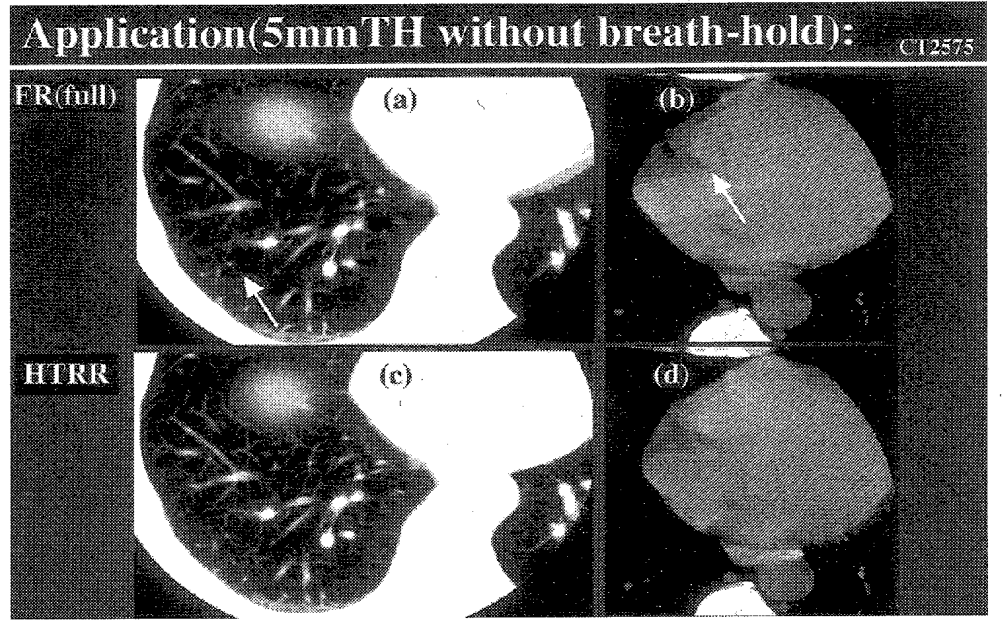

Fig. 9 Typical images obtained with an HTRR algorithm without breath-hold.

(a), (b): Images obtained with an HTRR algorithm.

(c), (d): images obtained with a full reconstruction algorithm. With an HTRR algorithm, streak artifacts caused by breath disappear, and a sharp cardiac silhouette is obtained.

Table 2 Performance states of the three algorithms in regard to temporal resolution and motion artifact.

\begin{tabular}{c|c|c}
\hline \hline Recon. type & Artifact reduction & Temporal resolution \\
\hline FR (full) & Bad & Bad \\
HTRR & Good & Good \\
HR (half) & Bad & Good \\
\hline
\end{tabular}

\section{謝 辞}

本研究のために不可欠なソフトの開発を行っていた だいたGE横河メデイカルシステムCT技術部の佐藤彰 子氏に深く感謝します。また，本研究のために貴重な 臨床データの収集に協力をしていただいた東京女子医 大 中央放射線部の大橋俊夫氏，ならびに研究に関す る貴重な助言を頂いた広島大学 放射線科の粟井和夫 氏にも厚く御礼を申し上げます。

\section{参考文献}

1) Kimura F, Shen $Y$, Date $S$, et al.: Thoracic aortic aneurysm and aortic dissection: new endoscopic mode for three-dimensional CT display of aorta. Radiology, 198 (2), 573-578, (1996).

2) 木村文子, 沈雲, 吉田勢津, 他: 新しい心電図同期再 構成法を用いたへリカルCT. 日本医放会誌，57(4)，217219, (1997).

3) 木村文子; 沈 雲, 望月高明：ヘリカルCTの心疾患への 応用. 臨床画像, 14(4), 80-87, (1998).

4) 安野泰史, 近藤 武, 片田和廣, 他: Helical scanning CT による冠動脈の描出．日本医放会誌，53(9)，1033-1039, (1993).
5）望月輝一, 田中宏明, 小山靖史, 他：CT-Ventriculography 一ヘリカルCTの心イメージングへの忘用一. 日本医放会 誌, $57(9)$, 605-607, (1997).

6）石風呂実, 澤本恵美, 安部伸和, 他: Subsec applicationに よる心臓のモーションアーチファクトの低減一第二報 HRCTに抒ける臨床的評洒一, 日放技会誌, 第54回総会 (子 稿集), 182, (1998).

7) 酒井文和, 沈雲, 堀内哲也, 他: Subsecond Scan と special cine reconstruction algorithmを利用した胸部高分解 能CT画像における心拍動アーチファクト軽減の試み.日本 医放会誌，58(6)，296-298，(1998).

8) Crawford CR and King KF: Computed tomography scanning with simultaneous patient translation. Med.Phys., 17 (6), $967-$ 982, (1990). 
Fig. 1 HTRRアルゴリズムの概要図.

(b)はHTRRアルゴリズムである三角形的なweight functionを示すとともに, HTRRアルゴリズムの奏効的な時間分解能の プロフィールも示している，一方，従来のfullリコンアルゴリズムとhalfリコンアルゴリズムの実效的な時間分解能のプロ フィールはそ狄ぞれ(a)と(c)で示されている。

Fig. 2 心臟ファントム (pulsating cardiac phantom).

(a)は心葴ファントムの全体図を圭している。(b)と (c) はそれぞ机心臓ファントムの静止状態時の収縮期(ES) と搪張期(ED) を示している。

Fig. 32 種類のスキャンモード.

(a) cluster scan mode.

(b) cine scan mode. cine scan mode画像はoverlapping再構成技術によって得られた。

Fig. 4 拍動心臓ファントムの結果.

(a)はつアントム静止状態の横断像を示す（b)－(e)は動的状態の上きの異なるアルゴリズムの結果を示す.

(b)60cycles/min. での従来のfull リコンアルゴリズムの結果.

(c) 40 cycles/min. での従来のfullリコンアルゴリズムの結果.

(d)60cycles/min.でのHTRRリコンアルゴリズムの結果。

(e) 40cycles/min.でのHTRRリコンアルゴリズムの)結果.

HTRRアルゴリズムは時間分解能の改善のみでなく，モーションアーチファクト軽減にも有効であることが分かる。

Fig. 5 空間分解能に関古るCATPHANファントムの結果.

三つのアルゴリズムによる空間分解能の比較。

(a)従来のfull コンアルゴリズムの結果.

(b)HTRRアルゴリズムの結果.

(c) 促来のhalfリコンアルゴリズムの結果.

(d) 空間分解能ファントムの全体図を示している。従来のfullリコンアルゴリズムが一番よい空間分解能を示している.

Fig. 6 密度分解能上ノイズに関吉るCATPHANファントムの䑩果.

$(\mathrm{a})$ - c c )上 (d) 一(f) はそ机ぞ扎密度分解能扔よびノイズの結果を示す.

(a)と(d)従来のfullリコンアルゴリズムの結果.

(b) と (e)HTRRアルゴリズムの結果.

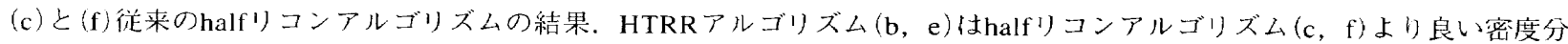
解能抢よびノイズの低減を得ることができる。

Fig. 7 cluster scan modeを施行した肺HRCT像.

(a)fullリコンアルゴリズムによる画像では，心陰影は二重線に見え(矢印)，さらに右中葉の肺血管㓌影の辺縁は不明瞭(2 本矢印)で，右下葉内側にもモーションアーチファクトによる陰影(矢頭)が䜑められる。

(b)HTRRアルゴリズムによる画像では，心陰影および肺血管の辺縁は鮮明で，モーションアーチファクトは著明に減少し ている.

(c)halfリコンアルゴリズムによる画像では，優れた時間分解能のため心陰影の辺縁は鮮明であるが，肺血管辺縁はやや不 明瞭であり(2本矩印)，モーションアーチファクトが残存している(短)。

Fig. 8 cine scan modeを施行した肺iHRCT像.

(a)—(c) はfullリコンアルゴリズム，(d)〜(f)はHTRRアルゴリズムによる画像. overlapping reconstruction施行後，時相の 異なる画像を抽出しているため，a， b , c および d, e , f は同位置，異時相の画像である(ただし， a と d, bと e, c と f (は同時相). fullリコンアルゴリズムでは, 左下葉の肺血管陰影はモーションアーチファクトのため 2 本に描出され(知印), モーションアーチファクトの程度は時相により異なる。HTRRアルゴリズムではいずれ時相でも，モーションアーチファ クトは目立たない。

Fig.9呼吸中にcluster scanにて撮像した画像

fullリコンアルゴリズム (a, b) と比較すると， HTRRアルゴリズム (c，d)では呼吸によるstreak artifact(矢印)は消失し，き らに心陰影の辺縁も鮮明である。

Table 1 異なるリコンアルゴリズムの寒効的な時間分解能の此較.

Table 2 実効的な時間分解能の改善とモーションアーチファクトの低減に関する異なるリコンアルゴリズムの比較。 